\title{
INFLUENCE OF BOULDERS ON NETLEAF HACKBERRY (CELTIS RETICULATA) GROWTH AND DISTRIBUTION IN THE WASATCH FOOTHILLS
}

\author{
Alex Argyle ${ }^{1}$ and Michael T. Stevens ${ }^{1,2}$
}

\begin{abstract}
In a landscape, abiotic features, such as boulders, influence microhabitats and consequently affect patterns of vegetation. We hypothesized that boulders in the foothills of the Wasatch Mountains east of Provo, Utah, affected the growth patterns of netleaf hackberry (Celtis reticulata) by providing shade on their north faces. To test this hypothesis, we set up 3 transects $6 \mathrm{~m}$ wide and up to $50 \mathrm{~m}$ long. Along these transects, we measured all hackberries taller than $30 \mathrm{~cm}(n=249)$. We recorded whether the hackberries grew within $0.5 \mathrm{~m}$ of a boulder that was at least $0.5 \mathrm{~m}$ along one dimension. We found that hackberries at our study site were more likely to be associated with boulders $(n=$ $225 ; 90.4 \%)$ than to be growing alone $(n=24 ; 10.7 \%)\left(\chi^{2}=162.25, \mathrm{df}=1, P<0.001\right)$. For each hackberry associated with a boulder, we took a direction bearing from the center of the boulder to the place where the hackberry was rooted. We found that hackberries associated with boulders were more likely to grow near the south $(n=92 ; 40.9 \%)$ side than near the north $(n=35 ; 15.6 \%)$, west $(n=55 ; 24.4 \%)$, or east sides $(n=43 ; 19.1 \%)\left(\chi^{2}=33.90\right.$, df $\left.=3, P<0.001\right)$. These results suggest that boulders influence patterns of hackberry growth and may actually provide thermal radiation that melts snow in the Wasatch foothills, rather than shade protection as we had originally hypothesized.
\end{abstract}

RESUMEN.-Las características abióticas de un paisaje, tales como los peñascos, afectan los patrones de vegetación debido a su influencia en los microhábitats. Establecimos la hipótesis de que los peñascos en la ladera de las montañas Wasatch, al este de Provo, Utah, afectan los patrones de crecimiento del almez occidental (Celtis reticulata) al proyectar sombra en las caras del norte. Con el fin de comprobar dicha hipótesis, trazamos tres transectos de seis metros de ancho y hasta $50 \mathrm{~m}$ de longitud. En cada transecto medimos todos los árboles $(n=249)$ cuya altura superara los $30 \mathrm{~cm}$. Registramos si los árboles crecían a una distancia de $0.5 \mathrm{~m}$ de un peñasco que estaba situado al menos $0.5 \mathrm{~m}$ a lo largo de una dimensión. Encontramos que los árboles de C. reticulata tenían más posibilidades de crecer si había peñascos $(n=225$; $90.4 \%)$ que de manera aislada $(n=24 ; 10.7 \%)\left(\chi^{2}=162.25\right.$, df $\left.=1, P<0.001\right)$. Entre los que crecían con los peñascos, medimos la dirección del crecimiento utilizando la brújula electrónica de un teléfono celular para determinar hacia qué cara del peñasco tenían mayor tendencia a crecer; descubrimos que los árboles asociados con la existencia de peñascos tenían más posibilidades de crecer cerca del lado sur $(n=92 ; 40.9 \%)$ que del lado norte $(n=35 ; 15.6 \%)$, oeste $(n=55$; $24.4 \%)$ o este $(n=43 ; 19.1 \%)\left(\chi^{2}=33.90, \mathrm{df}=3, P<0.001\right)$. Estos resultados nos indican que los peñascos tienen influencia en los patrones de crecimiento del Celtis reticulata y que, de hecho, tal vez puedan radiar calor que derrite la nieve en las laderas de las montañas Wasatch, en lugar de proyectar sombra como establecimos en nuestra hipótesis original.

Plants benefit from microclimate-stabilizing nurse objects, such as rocks, especially when harsh conditions prevail (Nobel et al. 1992, Signell and Abrams 2006, Shitzer et al. 2008, Carlucci et al. 2011), and have varying degrees of reliance on such objects (Kleier and Lambrinos 2005). In stressful environments where beneficial features are not randomly distributed, plants may show clumped distributions clustered around those features. One reason for this pattern could be the utilization of microclimates created by nurse objects.

We assessed a possible association between netleaf hackberry (Celtis reticulata) and boulders. Hackberry is a common shrub in the northern mountain brush community of the Wasatch Mountains in Utah. It grows on xeric foothills $(880-1800 \mathrm{~m})$ that are often strewn with boulders. A member of the hemp family (Cannabaceae), hackberry is characterized by rough leaves with a reticulated vein pattern. Hackberry produces fruit that is an important food source for birds, especially during winter months (Van Buren et al. 2011).

The Wasatch Mountains are in the colddesert biome. As the name implies, cold deserts have low temperatures for at least one part of the year and experience chronically dry

\footnotetext{
${ }^{1}$ Department of Biology, Utah Valley University, 800 West University Parkway, Orem, UT 84058

2Corresponding author. E-mail: michael.stevens@uvu.edu
} 
conditions. Cold deserts have low precipitation due to their location within a large landmass or in a rain shadow and typically get most of their water in the form of snow during winter months (Gurevitch et al. 2006). The study site in the Wasatch foothills is characterized by temperature extremes (Hayward 1948) that may be severe enough to encourage patterning among plants, such as hackberry, that may rely on the moderating effects of nurse objects for establishment and growth.

Our goal was to determine (1) whether hackberry is more likely to grow in association with a boulder than to grow alone and (2) on which side of a boulder hackberry is most likely to grow. Because of the temperature extremes in the Wasatch foothills, we hypothesized that hackberry was more likely to grow in association with a temperature-stabilizing boulder than to grow alone. Additionally, we hypothesized that the intense heat of the Wasatch foothills would cause hackberry to associate with boulders on their north-facing sides, as the north face of a boulder is relatively shady and cool in the Northern Hemisphere.

\section{Methods}

The Wasatch Mountains in northern Utah rise abruptly from the valley floor (below 1400 $\mathrm{m}$ ) to heights over $3600 \mathrm{~m}$. Y Mountain (elevation $2612 \mathrm{~m}$ ) is the peak directly east of Provo, Utah. Our study site $\left(40^{\circ} 15^{\prime} \mathrm{N}, 111^{\circ} 38^{\prime}\right.$ $\mathrm{W}$, elevation $1591 \mathrm{~m}$ ) is located in the foothills east of Provo at the base of Y Mountain near the study site of Hayward (1948). The area receives $50.2 \mathrm{~cm}$ of precipitation a year and has an average annual temperature of $11.9{ }^{\circ} \mathrm{C}$ (1981-2010) (NOAA-NWS 2010).

To test whether the presence of boulders affected the growth and distribution of hackberries in the northern mountain brush community of the Wasatch Mountain foothills, we set up 3 transects in the summer of 2012 (Fig. 1). Our transects were $6 \mathrm{~m}$ wide and up to $50 \mathrm{~m}$ long. Each of them ran directly west $\left(270^{\circ}\right)$. The slope and aspect in the vicinity of transects $1-3$ were $20 \%$ and $185^{\circ}, 21 \%$ and $190^{\circ}$, and $30 \%$ and $322^{\circ}$, respectively.

Along each transect, we measured the height of every hackberry that was $\geq 30 \mathrm{~cm}$ tall and determined whether it was growing in association with a boulder. Boulders were defined as rocks that were $\geq 0.5 \mathrm{~m}$ in one dimension.
Hackberries that were $>0.5 \mathrm{~m}$ away from a boulder were recorded as growing alone, whereas hackberries growing $\leq 0.5 \mathrm{~m}$ from a boulder were recorded as growing in association with a boulder. For each hackberry associated with a boulder, we used an electronic compass on a mobile phone to take a bearing from the center of the boulder to the place where the hackberry was rooted. This method allowed us to determine which boulder face the hackberry grew nearest to.

We conducted chi-square tests to determine whether the observed number of hackberries growing in association with boulders versus the number growing alone differed from the expected numbers (equal numbers in the 2 categories) and whether hackberries associated with boulders were more likely to grow on one side of a boulder versus another. To determine whether hackberry height was affected by growth position relative to a boulder, we used ANOVA. To determine whether hackberry height was affected by the presence or absence of a boulder, we used a $t$ test. All data were analyzed using JMP Version 10.0.2 (SAS Institute, Inc. 2012).

\section{RESUlTS}

At our study site, the vast majority of the hackberries surveyed $(n=249)$ were associated with boulders $(n=225 ; 90.4 \%)$, with the minority growing alone $(n=24 ; 10.7 \%)$ $\left(\chi^{2}=162.25, \mathrm{df}=1, P<0.001\right)$. Among hackberries associated with boulders, more grew on the south $(n=92 ; 40.9 \%)$ side than on the north $(n=35 ; 15.6 \%)$, west $(n=55 ; 24.4 \%)$, or east $(n=43 ; 19.1 \%)$ sides of boulders $\left(\chi^{2}=\right.$ 33.90 , $\mathrm{df}=3, P<0.001)$. We also discovered the possibility that the tallest hackberries grew on the west sides of boulders $(F=2.48$, $\mathrm{df}=3, P=0.062$ ). However, hackberry height was not affected by the presence or absence of a boulder $(t=-0.550, \mathrm{df}=1, P=$ $0.586)$.

\section{DisCuSSION}

There are several reasons why boulders may be favorable to the establishment, survival, and growth of plants such as the hackberry. Boulders aid in snowmelt by means of radiative properties (Jury and Bellantuoni 1976a, Nobel et al. 1992). Boulders also increase moisture infiltration into soils (Epstein 




Fig. 1. Overhead view of our transects (1-3) in the foothills of Y Mountain. Contour intervals are $12.2 \mathrm{~m}$. The paved area in the northwest corner of the map is the southern end of 1550 East, a street in Provo, Utah.

et al. 1966), decrease erosion (Lamb and Chapman 1943), promote water flow (Jury and Bellantuoni 1976b), lower evaporation rate (Lamb and Chapman 1943, Jury and Bellantuoni 1976b, Nobel et al. 1992), increase root proliferation (due to greater water availability) (Nobel et al. 1992), aid in vertebrate-mediated seed dispersal (Carlucci et al. 2011), offer protection from herbivores (Shitzer et al. 2008), and prevent fire damage (Signell and Abrams 2006).

That more than $90 \%$ of hackberries surveyed were associated with boulders strongly suggests that boulders provide some type of benefit to the hackberries. However, the benefit was not for the reason we originally hypothesized. Forty-one percent of the hackberries we surveyed grew on the sunny south face of boulders, which counters our original hypothesis that hackberries would be more likely to grow in the shade of a boulder's north side. The environmental conditions in the colddesert biome provide clues as to how the microclimate of a boulder affects hackberry. In addition to summer heat, winter represents another temperature extreme that may hold greater importance to the life cycle of the 
hackberry. Because most cold-desert water comes in the form of snowmelt (Gurevitch et al. 2006), an object capable of promoting snowmelt during the spring months can be key to survival. Boulders retain heat gathered during the day (Nobel et al. 1992) and radiate it out slowly at night (Jury and Bellantuoni 1976a). The properties of heat retention and transfer may be enough to aid in melting snow. The radiative properties of boulders may ameliorate harsh winter conditions and could be especially advantageous in the late winter-early spring transition, because melting snow could give the hackberry more usable water early in the season. Extra water (and the lack of snow cover) is especially important for seedlings and saplings as they become established.

Our results showed a strong and positive association between hackberries and boulders. Other researchers have found similar associations. In the tropical alpine puna ecosystem in Chile, Kleier and Lambrinos (2005) found positive associations between boulders and Polylepis tarapacana, a short shrubby tree that grows at high elevations, and also between boulders and Tephrocactus ignescens, a cushion-forming cactus. The boulder association was not obligate in the case of hackberry or Polylepis tarapacana, but the cactus was found only in the presence of a boulder or a bunchgrass facilitator (Kleier and Lambrinos 2005). Their results suggest that boulders provide a benefit to plants, but that each plant has a different dependence on the microclimate provided by a boulder or a plant facilitator.

In addition to finding hackberries often associated with boulders, we found them more likely to be growing on a boulder's south side. In the study by Nobel et al. (1992), a different directional pattern was found for agave in the Sonoran Desert. They found 5-fold root proliferation on the north side of boulders compared to 3-fold root proliferation on the south side of boulders. This demonstrates that in their area of study, the north side of a boulder may be more favorable to growth than the south side. This finding differs from ours for the following possible reasons. In the Wasatch foothills, water may be relatively less important as a determinant of growth or survival as compared to the Sonoran Desert. Additionally, although shade on the north side of a boulder could be beneficial in the summer (especially in a hot desert), the associated snow accumulation on the north sides of boulders could be problematic in the cold desert of Utah. In contrast, the Nobel et al. (1992) study took place in the hot desert of southern California, with comparatively mild winters and little snow accumulation. Seasonal differences are also a key factor, as the majority of precipitation in Utah comes during winter months, which means that the sooner the snow melts, the sooner the water can be utilized by a hackberry.

One factor that likely contributes to the hackberry-boulder association is seed dispersal by animals. Such dispersal is important in fruiting plants and may affect plant distribution. For instance, Carlucci et al. (2011) found that seed dispersal by vertebrates was important to Brazilian forest expansion and that mammals and birds dispersed seeds near the rocks they used as perches. Similarly, C. reticulata is an important food source for birds (Van Buren et al. 2011), which means boulders may be used as perches; thus, the areas around boulders should have greater abundances of seeds and potentially seedlings. Also, some animals may prefer the sunny south sides of boulders for basking, making seed dispersal via vertebrates more likely on one side of a boulder than another.

The benefits of the hackberry-boulder association appear to be mainly in helping seedlings establish, as we did not find the mean height of hackberries associated with boulders to be greater than the height of those growing alone. A hackberry's position with respect to a boulder, however, may affect height, as we found hackberry height on the west face of boulders to be marginally greater than hackberry height on the other sides of boulders. This finding suggests there may be some long-term advantage to being on the west side of a boulder. Hackberries were most commonly located on a boulder's south side, but were second-most likely to be growing on the west side. Perhaps the south and west sides of boulders in this area are favorable to hackberry because the entire Wasatch Mountain Range faces generally west and secondarily south.

\section{Conclusions}

The microclimates created by boulders provide better conditions for hackberry establishment (and perhaps growth), especially 
microclimates on south and west boulder faces. The positive influence of an abiotic feature in the landscape is potentially substantial. In fact, a boulder provides benefits to a plant similar to those provided by a nurse plant, but without the future problems associated with plant-plant competition (Kleier and Lambrinos 2005). Boulders may be a key factor in allowing hackberry to become established and grow in the stressful environment of the Wasatch Mountain foothills.

\section{ACKNOWLEDGMENTS}

We thank Renée Van Buren, Bob Robbins, Jim Harris, Kate McPherson, and Allen Hill for their comments on the manuscript. Mike Bird and Jason Hill produced the map. Two anonymous reviewers and Bob Nowak helped us improve the manuscript. This project was part of Alex Argyle's honors thesis at Utah Valley University (Orem, UT). Funding was provided by the Scholarly Activities Committee of the College of Science \& Health at Utah Valley University.

\section{Literature Cited}

Carlucci, M.B., L. Da S. Duarte, and V.D. Pillar. 2011. Nurse rocks influence forest expansion over native grassland in southern Brazil. Journal of Vegetation Science 22:111-119.

Epstein, E., W.J. Grant, and R.A. Struchtemeyer. 1966. Effects of stones on runoff, erosion, and soil moisture. Soil Science Society of America Journal 30: 638-640.

Gurevitch, J., S.M. Scheiner, and G.A. Fox. 2006. The ecology of plants. Sinauer Associates, Inc., Sunderland, MA.
Hayward, C.L. 1948. Biotic communities of the Wasatch chaparral, Utah. Ecological Monographs 18:473-506.

Jury, W.A., And B. Bellantuoni. 1976a. Heat and water movement under surface rocks in a field soil: 1 . Thermal effects. Soil Science Society of America Journal 40:505-509.

1976b. Heat and water movement under surface rocks in a field soil: 2 . Moisture effects. Soil Science Society of America Journal 40:509-513.

Kleier, C., AND J.G. LAmbrinos. 2005. The importance of nurse associations for three tropical alpine life forms. Arctic, Antarctic, and Alpine Research 37:331-336.

Lamb, J., Jr., and J.E. Chapman. 1943. Effect of surface stones on evaporation, soil temp, and moisture. Journal of the American Society of Agronomy 35: $567-578$.

[NOAA-NWS] National OCEANIC AND ATMOSPheric ADministration-National Weather Service. 2010. National Weather Service Forecast Office: Salt Lake City, UT. [Cited 28 June 2013]. Available from: http://www.nws.noaa.gov/climate/xmacis.php ?wfo $=$ slc

Nobel, P.S., P.M. Miller, and E.A. Graham. 1992. Influence of rocks on soil temperature, soil water potential, and rooting patterns for desert succulents. Oecologia 92:90-96.

SAS InstituTe, Inc. 2012. JMP Version 10.0.2. SAS Institute, Inc., Cary, NC.

Shitzer, D., I. NoY-Meir, and D.G. Milchunas. 2008. The role of geologic grazing refuges in structuring Mediterranean grassland plant communities. Plant Ecology 198:135-147.

SignelL, S.A., AND M.D. ABRAms. 2006. Influence of rocky landscape features and fire regime on vegetation dynamics in Appalachian Quercus forests. Journal of Vegetation Science 17:675-684.

Van Buren, R., J.G. Cooper, L.M. Shultz, and K.T. HARPER. 2011. Woody plants of Utah: a field guide with identification keys to native and naturalized trees, shrubs, cacti, and vines. Utah State University Press, Logan, UT.

Received 28 June 2013 Accepted 19 September 2013 